\title{
Гидрохимия речных вод Воронежской городской агломерации
}

\author{
Т. И. Прожорина ${ }^{\bowtie}$, С. А. Куролап, Н. В. Каверина \\ Воронежский государственный университет, Российская Федерация \\ (394018, г. Воронеж, Университетская пл., 1)
}

\begin{abstract}
Аннотация: Цель исследования - оценка качества вод Донского речного бассейна в пределах Воронежской городской агломерации.

Методы и материалы. В статье приведены результаты химического анализа состояния трех водотоков, протекающих в пределах 40-км зоны воздействия крупного промышленно развитого города Воронеж, в условиях повышенной техногенной нагрузки и формирующих гидрографический каркас донской речной системы: реки Дон (главный водоток) и двух его левых притоков - Воронеж и Усмань. Химический анализ приоритетных загрязняющих веществ в пробах речных вод проводился с применением органолептического, титриметрического, потенциометрического, кондуктометрического и колориметрического методов анализа.

Результаты. Повышенная антропогенная и рекреационная нагрузка в пределах Воронежской городской агломерации оказывает негативное влияние на качество вод донского речного бассейна, которое можно оценить в виде следующих классов качества вод: река Дон - «грязная»; река Воронеж «умеренно загрязненная»; река Усмань - «загрязненная».
\end{abstract}

Ключевые слова: разовая проба воды, химический анализ, органолептический анализ, класс качества воды, приоритетные загрязняющие вещества, антропогенное происхождение, рекреационная нагрузка, предельно-допустимая концентрация (ПДК), водоемы рыбохозяйственного назначения.

Источник финансирования: Исследование выполнено при финансовой поддержке РФФИ, проект № 20-05-00779.

Для цитирования: Прожорина Т.И., Куролап С.А., Каверина Н.В. Гидрохимия речных вод Воронежской городской агломерации // Вестник Воронежского государственного университета. Серия География. Геоэкология, 2020, № 3, c. 78-85. DOI: https://doi.org/10.17308/geo.2020.3/3027

\section{ВВЕДЕНИЕ}

Важным условием, формирующим экологическую ситуацию на территории агропромышленного региона интенсивного техногенного освоения, в том числе и Воронежской области, является водный фактор, который определяет особенности хозяйственно-питьевого водопользования и служит важнейшим рекреационным ресурсом в жизнедеятельности населения.

Эффективное использование речных вод без нанесения ущерба и вреда геосистеме реки и ее бассейну должно базироваться на строгом учете качества водного фонда, количественного и качественного состояния водотоков $[1,9]$.
Река Дон - главная водно-транспортная магистраль области, источник технического водоснабжения промышленных предприятий и сельскохозяйственных объектов, используется в рекреационных целях и для любительского рыболовства. Высокая степень антропогенной нагрузки на водотоки Донского бассейна и разнообразная промышленно-селитебная инфраструктура региона создают определенные экологические риски.

Основные источники загрязнения Дона связаны со сбросом неочищенных и недостаточно очищенных сточных вод с промышленных предприятий, объектов пищевой, перерабатывающей промышленности и жилищно-коммунального хозяй-

() Прожорина Т.И., Куролап С.А., Каверина Н.В., 2020

\ Прожорина Татьяна Ивановна, e-mail: coriandre@rambler.ru

Контент доступен под лицензией Creative Commons Attribution 4.0 License. 
ства, поверхностного стока с территорий городов и поселков, смывом с полей пестицидов и удобрений.

Река Воронеж - один из наиболее загрязненных притоков Дона. Качество речных вод ухудшается за счет загрязнения их промышленно-коммунальными стоками.

Водная экосистема реки Усмань испытывает повышенную рекреационную нагрузку в летний сезон года, Возможно поступление в реку загрязненных стоков от частного сектора, дорожной сети, а также частично - от применяемых ядохимикатов, удобрений, поступающих с близлежащих территорий пахотных земель [9].

В 2018 году на бассейне реки Усмань было обнаружено около 26 несанкционированных свалок бытового мусора, большая часть которых сосредоточена на правом берегу за мостом у пос. Боровое [10].

Департаментом природных ресурсов и экологии Воронежской области в 2018 году проведен мониторинг за состоянием дна, берегов, водоохранных зон и изменениями морфометрических особенностей водных объектов Воронежской области на реках Дон, Воронеж, Усмань. На реке Воронеж в районе села Чертовицы Рамонского района и реке Усмань в районе села Рыкань Новоусманского района отмечены наиболее серьезные нарушения режима использования водоохранных зон - в прибрежной защитной полосе ведется жилищное строительство; происходит выбивание луговой растительности поймы автомототранспортом; встречается большое количество неорганизованных свалок бытового мусора после многочисленных отдыхающих [2].

Для Воронежской промышленной городской агломерации актуальность исследований качества поверхностных вод особенно высока в связи с высокой плотностью населения и наличием многочисленных рассредоточенных источников экологического риска с химическим типом воздействия на водные объекты в долине главной водной артерии региона - реки Дон [10].

Цель исследования - оценка качества вод Донского речного бассейна в пределах Воронежской городской агломерации.

\section{МАТЕРИАЛЫ И МЕТОДЫ ИССЛЕДОВАНИЯ}

С учетом наиболее интенсивной антропогенной нагрузки на поверхностные водные ресурсы вблизи областного центра нами выделена ближайшая 40-км зона, ограничивающая город Воронеж, которую условно можно определить как «Воронежская городская агломерация».

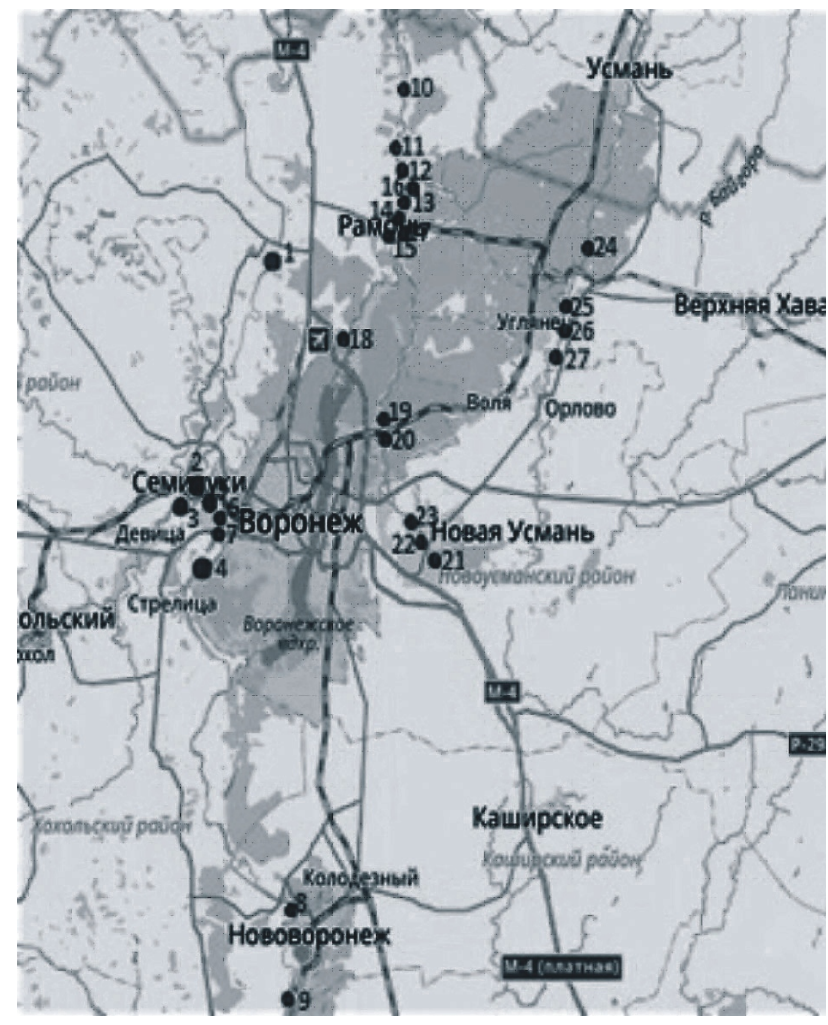

Puc. 1. Картосхема расположения точек отбора проб воды из рек Дон, Воронеж, Усмань

[Fig. 1. Map of the location of water sampling points from the Don, Voronezh, Usman' Rivers]

В качестве объекта исследования были выбраны три водотока, протекающие в пределах Воронежской городской агломерации, относящиеся к разным категориям по протяженности и составляющие общую часть Донской речной системы: река Дон - большая река (1967 км); река Воронеж средняя река (520 км) - левый приток реки Дон; река Усмань - водоток пограничного характера между средней и малой реками (151 км) - левый приток реки Воронеж [1].

Отбор разовых проб воды осуществлялся на расстоянии 1,5-2,0 м от берега реки, с поверхностного слоя 30-50 см с помощью батометра, согласно ГОСТу ${ }^{1}$. Работа проводилась в осенний период 2019 года. Всего было отобрано 27 проб, в том числе из реки Дон - 9 проб (№ 1-9), из реки Воронеж - 9 проб (№ 10-18), из реки Усмань - 9 проб (№ 19-27).

На рисунке 1 представлена картосхема расположения точек отбора проб воды из исследуемых водотоков.

Химический анализ приоритетных загрязняющих веществ в пробах речных вод проводился на

${ }^{1}$ ГОСТ 31861-2012 Вода. Общие требования к отбору проб. Москва, Стандартинформ, 2013. 36 с. 
базе аттестованной эколого-аналитической лаборатории факультета географии, геоэкологии и туризма Воронежского госуниверситета с применением следующих методов анализа: органолептический (прозрачность, наличие осадка, цветность, запах), титриметрический (общая жесткость, $\mathrm{Ca}^{2+}$, $\left.\mathrm{HCO}_{3}^{-}, \mathrm{SO}_{4}{ }^{2-}, \mathrm{Cl}^{-}\right)$; потенциометрический $(\mathrm{pH})$; кондуктометрический (общая минерализация), колориметрический $\left(\mathrm{Fe}_{\text {общ, }}, \mathrm{NO}_{3}^{-}, \mathrm{NO}_{2}^{-}, \mathrm{NH}_{4}^{+}\right)$и расчетный $\left(\mathrm{Mg}^{2+}\right)[6,8]$. Каждая проба анализировалась в двухкратной повторности по 16 показателям. Для химического анализа природных вод использованы методики выполнения измерений (МВИ), включенные в государственный реестр МВИ².

\section{ОБСУЖДЕНИЕ РЕЗУЛЬТАТОВ}

Согласно результатам органолептических исследований наибольшей изветностью обладают воды реки Воронеж (40 град) и две пробы реки Дон (№ 6, 7), имеющие цветность 50 и 40 град соответственно. Пробы № 21, 22 реки Усмань характеризуются повышенной цветностью до 50 град, а проба № 26 отличается наибольшей цветностью до 70 град. Цветность вод объясняется наличием в водоеме тонкодисперсных взвесей естественного или антропогенного происхождения. Повышенные значения цветности вод отдельных проб объясняются высокой нагрузкой со стороны промышленных и сельскохозяйственных предприятий [9].

Наиболее интенсивный запах отмечен в одной пробе воды из реки Дон (№6) и реки Усмань (№ 26), что очевидно связано, в первую очередь,

\footnotetext{
${ }^{2}$ Методика выполнения измерений массовой концентрации ионов аммония в природных и сточных водах фотометрическим методом с реактивом Несслера. ПНД Ф 14.1:2.1-95; Методика выполнения измерений массовой концентрации железа в природных и сточных водах фотометрическим методом с о-фенантролином. ПНД Ф 14.1:2.2-95; Методика измерений массовой концентрации нитрит-ионов в питьевых, поверхностных и сточных водах фотометрическим методом с реактивом Грисса. ПНД Ф 14.1:2:4.3-95 (издание 2011 г.); Методика выполнения измерений содержаний кальция в пробах природных и очищенных сточных вод титриметрическим методом. ПНД Ф 14.1:2.95-97; Методика выполнения измерений содержаний хлоридов в пробах при родных и очищенных сточных вод аргентометрическим методом. ПНД Ф 14.1:2.96-97; Методика выполнения измерений жесткости в пробах природных и очищенных сточных вод титриметрическим методом. ПНД Ф 14.1:2.98-97; Методика выполнения измерений содержаний гидрокарбонатов в пробах природных вод титриметрическим методом. ПНД Ф 14.2.99-97; Методика выполнения измерений $\mathrm{pH}$ в водах потенциометрическим методом. ПНД Ф 14.1:2:3:4.121-97 (издание 2004 г.); Методика выполнения измерений массовой концентрации сульфат-ионов в пробах природных и сточных вод турбидиметрическим методом. ПНД Ф 14.1:2.159-2000.
}

со сбросом недостаточно очищенных вод с правобережных очистных сооружений города Воронежа и села Углянец Верхнехавского района.

Органолептические показатели не нормируются для вод рыбохозяйственного назначения, однако их повышенные значения могут косвенно свидетельствовать о техногенном загрязнении вод.

Химический анализ речных вод проводился для ряда наиболее приоритетных компонентов. На основании полученных результатов химического состава водных проб был проведен сравнительный анализ определяемых ингредиентов с предельнодопустимыми концентрациями (ПДК) загрязняющих веществ для водоемов рыбохозяйственного назначения [7].

Анализ результатов показал, что концентрации основных макрокомпонентов - ионов кальция $\left(\mathrm{Ca}^{2+}\right)$ и магния $\left(\mathrm{Mg}^{2+}\right)$, хлоридов $\left(\mathrm{Cl}^{-}\right)$, гидрокарбонатов $\left(\mathrm{HCO}_{3}^{-}\right)$лежат в пределах допустимых значений и удовлетворяют нормативам ПДК. Исключение составляют единичные пробы в реке Дон: в пробе № 9 содержание $\mathrm{Mg}^{2+}$-иона превышает норму в 1,05 раза; в пробе № 6 содержание $\mathrm{HCO}_{3}^{-}$- иона превышает норму в 1,1 раза.

В реках Дон и Усмань обнаружено повышенное содержание такого макрокомпонента как сульфат-ион. В частности, в реке Дон практически все пробы (за исключением № 3 и № 5) имеют содержание $\mathrm{SO}_{4}{ }^{2-}$ - иона выше нормы от 1,12 до 1,93 раза (при ПДК $\leq 100$ мг/л), а в реке Усмань в 4 пробах (№ 20, 21, 22, 23) содержание сульфатов превышает норму от 1,05 до 1,26 раза.

Сульфаты относятся к макрокомпонентам, постоянно присутствующим в природных водах, что обусловлено растворением гипса, а также переносом с дождями содержащихся в воздухе $\mathrm{SO}_{4}{ }^{2-}-$ ионов. Однако их количество зависит от погодных условий, времени года и не оказывает токсического воздействия на человека [8].

Значения показателя общей минерализации находятся в пределах нормы, за исключением единичной пробы № 26 реки Усмань (1349 мг/л), которая превышена в 1,35 раза. Это можно объяснить сбросом недостаточно очищенных стоков с очистных сооружений села Углянец Верхнехавского района. Расчет усредненных значений минерализации (по 9 пробам для каждого водотока) показал, что река Дон характеризуется значением 435 мг/л, река Воронеж - 533 мг/л, а воды реки Усмань отмечены самым высоким значением минерализации, достигающим 733 мг/л. 
Класс качества вод в зависимости от $\mathrm{pH}$

[Table 1. Water quality class depending on $\mathrm{pH}$ ]

\begin{tabular}{|l|c|c|}
\hline \multicolumn{1}{|c|}{$\begin{array}{c}\text { Степень загрязнения/ } \\
\text { Pollution level }\end{array}$} & $\begin{array}{c}\text { Класс качества/ } \\
\text { Quality class }\end{array}$ & $\begin{array}{c}\text { Значение } \mathrm{pH} / \\
\text { PH value }\end{array}$ \\
\hline Предельно чистая/ Extremely clean & 1 & 7,0 \\
\hline Чистая/ Сlean & 2 & $6,0-6,9 / 7,1-7,9$ \\
\hline Удовлетворительно чистая/ Clean and satisfactory & 3 & $5,6-5,9 / 8,0-8,3$ \\
\hline Загрязненная/ Contaminated & 4 & $5,5-5,6 / 8,4-8,7$ \\
\hline Грязная/ Dirty & 5 & $5,3-5,4 / 8,8-9,5$ \\
\hline
\end{tabular}

Измерения водородного показателя ( $p H)$ показали, что для всех проб воды полученные значения лежат в диапазоне от 6,5 до 8,5 , а значит соответствуют требуемым нормативам. В зависимости от значений водородного показателя природные поверхностные воды классифицируются по следующим классам качества (таблица 1) [7].

Таким образом, к «условно чистым» водам относятся все 9 проб воды реки Воронеж; 4 пробы (№ 5, 6, 7, 9) реки Дон и 4 пробы (№ 24, 25, 26, 27) реки Усмань, отобранные на территории Воронежского биосферного заповедника в Рамонском районе и селе Углянец Верхнехавского района.

Как «удовлетворительно чистые» характеризуются воды реки Дон - 5 проб (№ 1, 2, 3, 4, 8), отобранные у села Новоживотинное Рамонского района и города Семилуки; пос. Тепличный (город Воронеж) и города Нововоронеж ниже сброса сточных вод с очистных сооружений «Аквасервис»; реки Усмань - 5 проб (№ 19, 20, 21, 22, 23) на территории пос. Боровое, пос. Сомово и села Новая Усмань [3].

Важным свойством, имеющим большое значение при водопользовании, является жесткость воды, которая может варьировать в широких пределах в зависимости от погодных условий, сезона года и типа почв. Исходя из классификации гидрохимика О. А. Алекина [8], по величине жесткости различают воды: очень мягкие ( $\left.<1,5^{\circ} \%\right)$, мягкие (1,5-3,0 ${ }^{\circ}$ Ж), умеренно жесткие (3,0-6,0 ${ }^{\circ}$ Ж), жесткие (6,0-9,0 ^Ж), очень жесткие (>9,0 ^Ж).

Согласно результатам анализов проб воды из реки Дон и реки Воронеж имеют «среднюю» жесткость, а «жесткие» воды характерны для реки Усмань. В 6 пробах реки Усмань (№ 19, 20, 21, 22, $23,24)$, отобранных в черте города Воронежа, села Новой Усмани и Воронежском биосферном заповеднике, величина общей жесткости составляет от 6,28 до 6,9 ${ }^{\circ}$ Ж.

Нитратный азот $\left(\mathrm{NO}_{3}^{-}\right)-$важный санитарный показатель. Он указывает на антропогенное заг- рязнение водной среды. Повышенное содержание нитратов в воде может служить индикатором загрязнения водоемов в результате распространения химических или органических загрязнений, источниками которых являются промышленные и сельскохозяйственных предприятия, поверхностные стоки с пастбищ, молочных ферм, скотных дворов. Избыточное внесение в почву азотных удобрений приводит к нитратному загрязнению воды, в результате чего наблюдается процесс эвтрофикации водоема.

При этом $\mathrm{NO}_{3}^{-}-$ион в количестве от 78,0 до 87,4 мг/л (при норме $\leq 40$ мг/л) был обнаружен лишь в 3 пробах воды из реки Усмань (№ 25, 26, 27), отобранных выше и ниже сброса сточных вод с очистных сооружений села Углянец.

Нитрит-анионы $\left(\mathrm{NO}_{2}^{-}\right)$относятся к промежуточным продуктам биологического разложения азотсодержащих органических соединений. Благодаря способности превращаться в нитраты, $\mathrm{NO}_{2}^{-}$ - анионы практически отсутствуют в поверхностных водах. Поэтому наличие в анализируемой воде повышенного содержания нитритов свидетельствует о биологическом загрязнении вод, причем с учетом частично прошедшей трансформациии азотистых соединений из одних форм в другие [5].

Результаты анализа на присутствие азотистых соединений выявили практически во всех пробах воды превышение ПДК по нитритному и аммонийному азоту (рис. 2, 3).

Содержание нитритного азота превышает норму в следующих пробах воды, отобранных из реки Дон - в 8 пробах от 1,1 до 6,5 раза (за исключением пробы № 2, отобранной в городе Семилуки); из реки Воронеж - в 5 пробах (№ 11, 12, 14, 15, 18) от 1,1 до 1,5 раза; в реке Усмань - во всех пробах от 7,0 до 63,8 раза (за исключением пробы № 24 на территории Воронежского биосферного заповедника).

Большая часть проб вод с повышенными значениями содержания нитритного азота относится 


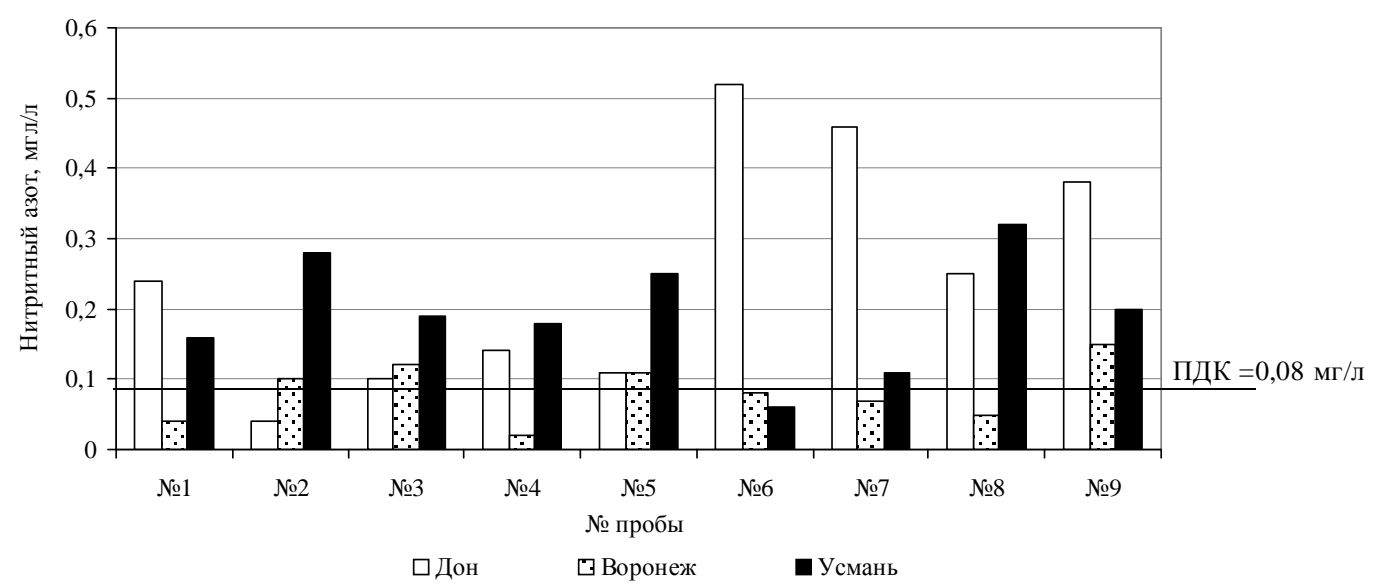

Pис. 2. Содержание $\mathrm{NO}_{2}^{-}-$иона в пробах воды, отобранных из рек Дон, Воронеж, Усмань

[Fig. 2. Content of $\mathrm{NO}_{2}^{-}-$ion in water samples from the Don, Voronezh, Usman' Rivers]

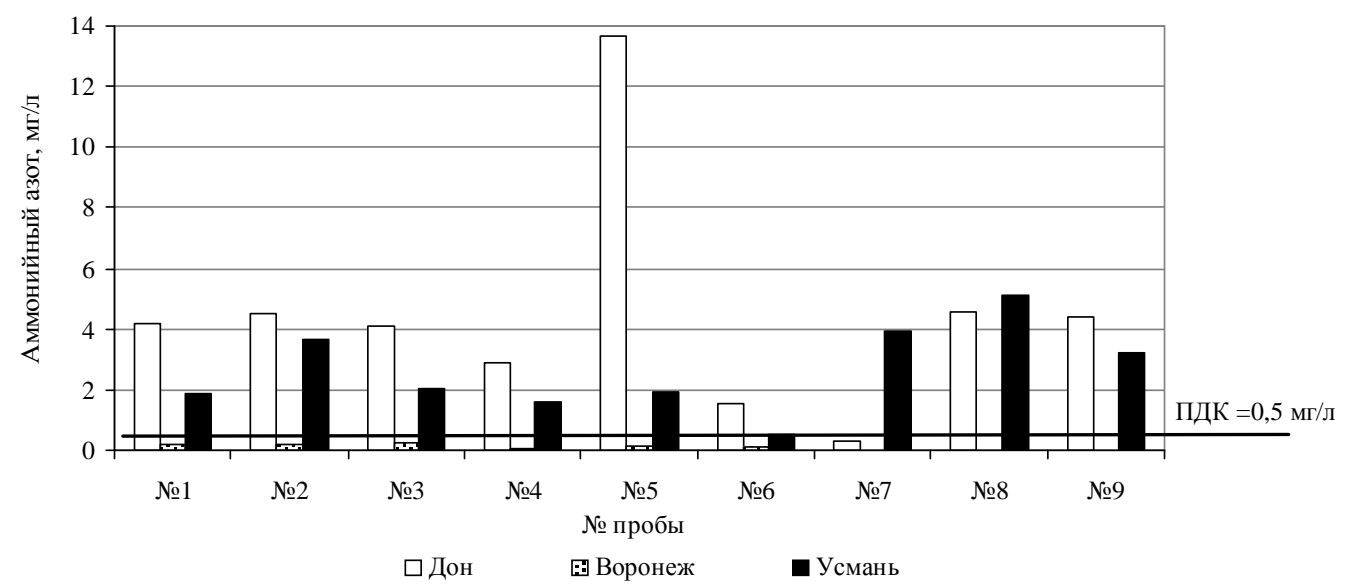

Puc. 3. Содержание $\mathrm{NH}_{4}^{+}-$иона в пробах воды, отобранных из рек Дон, Воронеж, Усмань

[Fig. 3. Content of $\mathrm{NH}_{4}^{+}$- ion in water samples from the Don, Voronezh, Usman' Rivers]

к следующим населенным пунктам: города Воронеж, Семилуки, Нововоронеж (на реке Дон); села Ступино и Чертовицы Рамонского района (на реке Воронеж); пос. Сомово (городской округ город Воронеж), села Новая Усмань и Углянец (на реке Усмань).

Ионы аммония $\left(\mathrm{NH}_{4}^{+}\right)$обычно рассматриваются как результат микробиологического разложения белков животного и растительного происхождения. Среди основных источников аммонийного загрязнения воды можно выделить поверхностные стоки, содержащие минеральные и органические удобрения, а также загрязняющие вещества от животноводческих комплексов $[4,5]$.

Содержание аммонийного азота превышает норму в водах реки Дон - в 8 пробах от 3,12 до 27,92 раза (за исключением пробы № 7, отобранной в городе Воронеже на 1000 м ниже сброса правобережных очистных сооружений); реки Усмань - во всех пробах от 1,12 до 10,2 раза.
Большая часть проб вод с повышенными значениями содержания аммонийного азота относится к следующим населенным пунктам: города Воронеж, Семилуки, Нововоронеж (на реке Дон); пос. Сомово (город Воронеж), села Новая Усмань и Углянец (на реке Усмань).

В соответствии с классификацией качества природных вод по содержанию аммонийного азота (таблица 2) был проведен сравнительный анализ степени загрязненности исследуемых речных вод, а именно: а) река Дон - воды «грязные», относятся к 5 классу качества; б) река Усмань - воды «загрязненные», 4 класс качества; в) река Воронеж - воды «умеренно загрязненные», 3 класс качества.

Анализ содержания суммарного железа практически во всех пробах воды позволил выявить превышение норматива ПДК для вод рыбохозяйственного назначения (ПДК $\mathrm{Fe}_{\text {общ }} \leq 0,1 \mathrm{мг/л).} \mathrm{Крат-}$ ность превышений ПДК находится в диапазоне: река Дон - в 8 пробах от 1,4 до 8,7 раза (за исклю- 
Содержание аммонийного азота в водоемах с различной степенью загрязненности [Table 2. The content of ammonium nitrogen in reservoirs with different pollution degree]

\begin{tabular}{|c|c|c|}
\hline $\begin{array}{c}\text { Степень загрязнения/ } \\
\text { Pollution level }\end{array}$ & $\begin{array}{c}\text { Класс качества/ } \\
\text { Quality class }\end{array}$ & $\begin{array}{c}\text { Aммонийный азот (мг/л)/ } \\
\text { Ammonium nitrogen (mg /l) }\end{array}$ \\
\hline Очень чистые/ Very clean & 1 & 0,05 \\
\hline Чистые/ Clean & 2 & 0,1 \\
\hline $\begin{array}{c}\text { Умеренно загрязненные/ } \\
\text { Moderately polluted }\end{array}$ & 3 & $0,2-0,3$ \\
\hline Загрязненные/ Contaminated & 4 & $0,4-1,0$ \\
\hline Грязные/ Dirty & 5 & $1,1-3,0$ \\
\hline Очень грязные/ Very dirty & 6 & $>3,0$ \\
\hline
\end{tabular}

чением пробы № 6); река Воронеж - в 6 пробах от 1,1 до 2,1 раза (за исключением пробы № 14, 15, 16); река Усмань - в 8 пробах от 1,4 до 3,6 раза (за исключением пробы № 20).

Повышенное содержание железа во всех пробах, видимо, обусловлено природным происхождением, характерным для вод Донского речного бассейна [2].

Для обобщения полученных результатов были рассчитаны средние значения основных веществ и соединений $\left(\mathrm{Fe}_{\text {обш. }}, \mathrm{NO}_{3}^{-}, \mathrm{NO}_{2}^{-}, \mathrm{NH}_{4}^{+}\right)$, характеризующих химический состав воды из рек Дон, Воронеж и Усмань (по 9 пробам для каждого водотока), результаты которых представлены в виде диаграммы (рис. 4).

Химический состав проб воды показал, что по содержанию приоритетных загрязняющих веществ, превышающих норматив для вод рыбохозяйственного назначения, водотоки можно расположить в следующий ряд по снижению качества вод: река Дон > река Усмань > река Воронеж.

\section{ЗАКЛЮЧЕНИЕ}

Анализ результатов гидрохимических исследований показал, что повышенная антропогенная и рекреационная нагрузка в пределах Воронежской городской агломерации оказывает негативное влияние на качество вод Донского речного бассейна. Воды агломерации по результатам гидрохимических анализов относятся к следующим классам качества: река Дон - «грязная»; река Воронеж - «умеренно загрязненная»; река Усмань - «загрязненная».

В целях охраны поверхностных вод от техногенного загрязнения Департаментом природных ресурсов и экологии Воронежской области постоянно ведется контроль и мониторинг состояния водных объектов. По данным на 2018 год результаты анализа состояния дна, берегов и водоохранных зон водных объектов Воронежской области

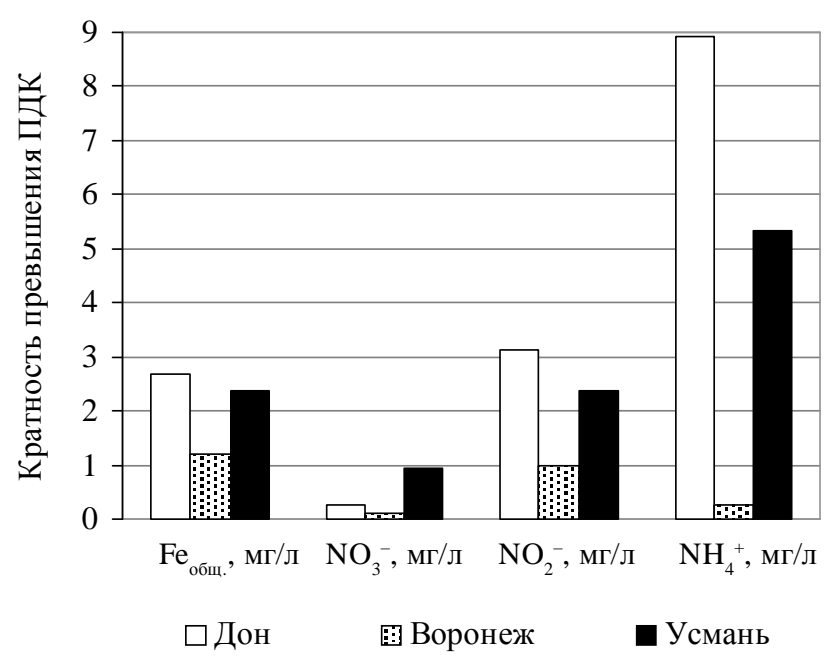

Pис. 4. Кратность превышения ПДК по основным загрязняющим веществам в пробах воды, отобранных из рек Дон, Воронеж, Усмань

[Fig. 4. Multiplicity of excess of MPC for the main pollutants in water samples taken from the Don, Voronezh, Usman' rivers]

показали, что состояние рек неудовлетворительное и требует проведения водоохранных и водохозяйственных мероприятий, включающих: организацию поверхностного стока, восстановление и экологическую реабилитацию рек, берегоукрепительные работы, а также принятие мер административного характера к нарушителям режима использования водоохранных зон [2].

\section{СПИСОК ЛИТЕРАТУРЫ}

1. Дмитриева В.А. Водные ресурсы Воронежской области в условиях меняющихся климата и хозяйственной деятельности. Воронеж, Издательский дом ВГУ, 2015. 92 c.

2. Доклад о состоянии окружающей среды на территории Воронежской области в 2018 году / Департамент природных ресурсов и экологии Воронежской области. Воронеж, 2019. 146 с. 
3. Корчагина В. А., Прожорина Т.И., Куролап С. А. Геоэкологическая экспресс-оценка качества поверхностных водных ресурсов Ближнего Подворонежья // Beстник Воронежского государственного университета. Серия География. Геоэкология, 2008, № 2, с. 64-70.

4. Маслова М.О., Пожорина Т.И., Якунина Н.И. Эколого-аналитическая оценка качества вод рекреационных зон ближнего Подворонежья // Вестник Воронежского государственного университета. Серия География. Геоэкология, 2014, № 4, с. 48-56.

5. Маслова М. О. Анализ содержания азотистых соединений в поверхностных водах рекреационных зон Воронежской городской агломерации // Экологическая оценка состояния городской среды, Воронеж, 2016, с. 82-91.

6. Каверина Н. В. и [др.] Методы экологических исследований: учебное пособие для вузов. Воронеж, издательство «Научная книга», 2019. 355 с.
7. Муравьев А.Г. Руководство по определению показателей качества воды полевыми методами. СанктПетербург, Крисмас+, 2009. 218 с.

8. Никаноров А. М. Гидрохимия. Санкт-Петербург, Гидрометеоиздат, 2001. 447 с.

9. Смольянинов В. М., Щербинина С. В. Интегральные показатели в оценке антропогенного давления на территорию речных водосборов Воронежской области // Материаль IV Всероссийской научной конференциии «Эколого-географические исследования в речных бассейнах». Воронеж, 2014, с. 191-196.

10. Экологические риски территорий интенсивного техногенного освоения / Под общей ред. проф. С.А. Куролапа и проф. О.В. Клепикова. Воронеж, издательство «Цифровая полиграфия», 2019. 192 с.

Конфликт интересов: Авторы декларируют отсутствие явных и потенциальных конфликтов интересов, связанных с публикацией настоящей статьи.

Поступила в редакциию 01.06.2020

Принята к публикацчи 26.07.2020

\title{
Hydrochemistry of River Waters in the Voronezh Urban Agglomeration
}

\author{
T. I. Prozhorina ${ }^{凶}$, S. A. Kurolap, N. V. Kaverina \\ Voronezh State University, Russian Federation \\ (1, Universitetskaya sq., Voronezh, 394018)
}

\begin{abstract}
The purpose of the study is to assess the water quality of the Don river basin within the Voronezh urban agglomeration.

Methods and materials. The article presents the results of a chemical analysis of the state of three watercourses flowing within a 40-km zone of influence of a large industrially developed city of Voronezh, under conditions of an increased technogenic load and forming the hydrographic framework of the Don river system: the Don River (the main watercourse) and its two left tributaries - the Voronezh and Usman' Rivers. Chemical analysis of priority pollutants in river water samples was carried out using organoleptic, titrimetric, potentiometric, conductometric and colorimetric methods of analysis.

Results. The increased anthropogenic and recreational load within the Voronezh urban agglomeration has a negative impact on the water quality of the Don river basin, which can be assessed in the form of the following water quality classes: Don River is "dirty"; Voronezh River is "moderately polluted"; Usman' River is "polluted".
\end{abstract}

Key words: single water sample, chemical analysis, organoleptic analysis, water quality class, priority pollutants, anthropogenic origin, recreational load, maximum permissible concentration (MPC), fisheries reservoirs.

Funding: The study was supported by the RFBR, project No. 20-05-00779.

(C) Prozhorina T.I., Kurolap S. A., Kaverina N. V., 2020

$\triangle$ Tat'yana I. Prozhorina, e-mail: coriandre@rambler.ru

The content is available under Creative Commons Attribution 4.0 License. 
For citation: Prozhorina T. I., Kurolap S. A., Kaverina N. V. Hydrochemistry of river waters in the Voronezh urban agglomeration. Vestnik Voronezskogo gosudarstvennogo universiteta. Geografia geoekologia, 2020, No. 3, pp. 78-85. (In Russ.) DOI: https://doi.org/10.17308/geo.2020.3/3027

\section{REFERENCES}

1. Dmitrieva V. A. Vodnye resursy Voronezhskoj oblasti v usloviyah menyayushchihsya klimata i hozyajstvennoj deyatel'nosti [Water resources of Voronezh Oblast in the context of changing climate and economic activities]. Voronezh, VSU Publ. House, 2015. 92 p. (In Russ.)

2. Doklad o sostoyanii okruzhayushchej sredy na territorii Voronezhskoj oblasti v 2018 godu [Report on the state of environment in the Voronezh Region in 2018]. Departament prirodnyh resursov i ekologii Voronezhskoj oblasti. Voronezh, 2019. 146 p. (In Russ.)

3. Korchagina V.A., Prozhorina T.I., Kurolap S.A. Geoekologicheskaya ekspressocenka kachestva poverhnostnyh vodnyh resursov Blizhnego Podvoronezh'ya [Geoecological express-evaluation of the surface water resources quality in the Middle Podvoronezh region]. Vestnik Voronezskogo gosudarstvennogo universiteta. Geografia geoekologia, 2008, no. 2, pp. 64-70. (In Russ.)

4. Maslova M. O., Prozhorina T. I., Yakunina N. I. Ekologo-analiticheskaya ocenka kachestva vod rekreacionnyh zon blizhnego Podvoronezh'ya [Ecological and analytical assessment of the water quality in recreationalareas of the Near Voronezh areas]. Vestnik Voronezskogo gosudarstvennogo universiteta. Geografia geoekologia, 2014, no. 4, pp. 48-56. (In Russ.)

5. Maslova M. O. Analiz soderzhaniya azotistyh soedinenij $v$ poverhnostnyh vodah rekreacionnyh zon Voronezhskoj gorodskoj aglomeracii [The analysis of the nitrogen compounds content in the surface waters of the Voron-

Прожорина Татьяна Ивановна

кандидат химических наук, доцент кафедры геоэкологии и мониторинга окружающей среды факультета географии, геоэкологии и туризма Воронежского государственного университета, г. Воронеж, Российская Федерация, ORCID: https://orcid.org/0000-0002-2808-0802, e-mail: coriander@ rambler.ru

Куролап Семен Александрович

доктор географических наук, профессор, декан факультета географии, геоэкологии и туризма Воронежского государственного университета, г. Воронеж, Российская Федерация, ORCID:

https://orcid.org/0000-0002-6169-8014, e-mail:

\section{skurolap@mail.ru}

\section{Каверина Наталия Викторовна}

кандидат географических наук, доцент кафедры геоэкологии и мониторинга окружающей среды факультета географии, геоэкологии и туризма Воронежского государственного университета, г. Воронеж, Российская Федерация, ORCID: https://orcid.org/0000-0001-7085-1466, e-mail: knataliy@mail.ru ezh city recreation zones]. Ekologicheskaya ocenka sostoyaniya gorodskoj sredy. Voronezh, Publ. House "Nauchnaya kniga”, 2016, pp. 82-91. (In Russ.)

6. Kaverina N. V. [et all.] Metody ekologicheskih issledovanij: uchebnoe posobie dlya vuzov [Methods of ecological research: a training manual for higher education institutions]. Voronezh, Publ. House "Nauchnaya kniga", 2019. 355 p. (In Russ.)

7. Murav'ev A. G. Rukovodstvo po opredeleniyu pokazatelej kachestva vody polevymi metodami [Manual for determination of water quality indicators by field methods]. St. Petersburg, Publ. "Krismas+", 2009. 218 p. (In Russ.)

8. Nikanorov A.M. Gidrohimiya [Hydrochemistry]. St. Petersburg, Gidrometeoizdat, 2001. 447 p. (In Russ.)

9. Smol'yaninov V. M., SHCHerbinina S. V. [Integral Indicators in Estimation of Anthropogenic Pressure on the Territory of Voronezh Oblast River Catchments]. Materialy IV Vserossijskoj nauch. konferencii "Ekologo-geograficheskie issledovaniya v rechnyh bassejnah" [Proc. of the IV All-Russ. Sci. Conf. "Ecological and Geographic Studies in River Basins"]. Voronezh, 2014, pp. 191-196. (In Russ.)

10. Ekologicheskie riski territorij intensivnogo tekhnogennogo osvoeniya [Ecological risks of intensive technogenic development territories]. Pod obshchej red. prof. S. A. Kurolapa i prof. O. V. Klepikova. Voronezh, Publ. "Cifrovaya poligrafiya", 2019. 192 p. (In Russ.)

Conflict of interests: The authors declare no information of obvious and potential conflicts of interest related to the publication of this article.

Received: 01.06.2020

Accepted: 26.07.2020

Tat'yana I. Prozhorina

Cand. (Chemist.) Sci., Associate Professor at the Department of Geoecology and Environmental Monitoring of the Faculty of Geography, Geoecology and Tourism, Voronezh State University, Voronezh, Russian Federation, ORCID: https://orcid.org/0000-0002-2808-0802, e-mail: coriandre@ rambler.ru

Semyen A. Kurolap

Dr. (Geogr.) Sci., Professor, Dean of the Faculty of Geography, Geoecology and Tourism, the Head of the Department of Geoecology and Environmental Monitoring, Voronezh State University, Voronezh, Russian Federation, ORCID: https://orcid.org/0000-0002-6169-8014, e-mail: skurolap@mail.ru

Nataliya V. Kaverina

Cand. (Geogr.) Sci., Associate Professor at the Department of Geoecology and Environmental Monitoring of the Faculty of Geography, Geoecology and Tourism, Voronezh State University, Voronezh, Russian Federation, ORCID: https://orcid.org/0000-0001-7085-1466, e-mail: knataliy@mail.ru 